International Journal of Language, Literature and Gender Studies (LALIGENS), Ethiopia

Vol. 5 (1), Serial No 11, February, 2016: 35-50

ISSN: 2225-8604(Print) ISSN 2227-5460 (Online)

DOI: http://dx.doi.org/10.4314/laligens.v5i1.4

\title{
Enhancing Senior Secondary Students Knowledge of English Grammar through Two Modes of Explicit Grammar Instruction in Ibadan Metropolis
}

\author{
Adedigba, J. O., Ph.D. \\ C/o Dr. D. O. Fakeye \\ Department of Teacher Education \\ University of Ibadan, Ibadan \\ Oyo State, Nigeria \\ E-mail: adedigbafemi@yahoo.com \\ Phone: +234803405981
}

\begin{abstract}
This study examined the effects of Direct Explicit Grammar (DEG) and Indirect Explicit Grammar (IEG) instructional strategies on achievement in English grammar and composition among secondary school students in Ibadan metropolis. The study adopted the pretest-posttest, control group, quasiexperimental design using a 3x3x2 factorial matrix. Three local government areas (LGAs) were randomly selected out of the five in Ibadan metropolis and three public schools were purposively selected from each LGA .Nine intact classes of 274 senior secondary II students were used for the study. The intact classes were randomly assigned to DEG, IEG and control groups respectively. Treatment lasted six weeks. The instruments used were: English Grammar
\end{abstract}


Achievement Test ( $\mathrm{r}=0.81$ ), English Composition Achievement Test (ECAT $\mathrm{r}$ $=0.84$ ) and Teachers Instructional Guides. Data were analyzed using Analysis of Covariance and Scheffe post-hoc test at 0.05 level of significance. Findings revealed that there was a significant main effect of treatment on students' achievement in English grammar $\left(\mathrm{F}_{(3,273)}=8.373 ; \mathrm{y}^{2}=0.03\right)$. The DEG group obtained the highest posttest achievement mean score $(\bar{x}=21.95)$ in English grammar, followed by IEG $(\bar{x}=21.88)$ and control $(\bar{x}=15.57)$ groups. Direct explicit and indirect explicit grammar instructional strategies enhanced students' achievement in English grammar and composition in public senior secondary schools in Ibadan metropolis. Teachers should adopt both strategies in teaching English grammar and composition for improved performance.

Key words: English grammar and composition, Direct and Indirect explicit grammar strategies, Senior secondary schools, Ibadan metropolis

The English language is a language of convenience, which has helped to weld together the various ethno-linguistic groups in the country. It is the official language, the language of education from the upper primary schools to higher institutions of learning in Nigeria and one of the core subjects in the Nigerian educational system (National Policy on Education, 2004). A minimum of a credit pass in English language is a prerequisite for admission into Nigerian higher institutions (Joint Admission and Matriculation Board, 2014). Also, a good knowledge of the different skills of the English language will enhance effective learning of all other subjects that are taught with the language in the Nigerian educational system. Despite the importance of English Language to students' academic advancement and success in the other school subjects, students' performance in the subject, especially in external examinations, has been very poor.

The poor performance of students in aspects of English that deal with writing has been identified as the major cause of the poor results they obtained in English Language in those years identified, and this has been traced to their ignorance of the grammatical rules of the English language and inability to use same to write effectively (WAEC Chief Examiners' Report, 2009). This trend is further confirmed in 2011 where the Chief Examiners' Report (2011) re-echoed candidates' weaknesses as including poor grammar and expressions, among others. The weaknesses exhibited by the candidates to include ignorance of parts of speech and ungrammatical expressions. It is apt to say that given the enormity of the problems exhibited by students, as contained in those reports, students may not be able to use grammar correctly in both spoken and written English and may not express ideas in correct sentences in composition, 
summary and comprehension, thereby making their chances of doing well in the entire English Language Paper 1 to be very remote.

Scholars (Celce-Murcia, 1991; Ellis, 2003; Ellis, 2006; Ellis, 2008; Fotos, 1994, and Olubodun, 2014) claimed that the only way candidates can get round the weaknesses exhibited in their writing is by studying the rudiments of the grammar of English language consistently. Thus, students of English language should strive to master the rudiments of the grammar of the language in order to improve upon their written and spoken expressions. The poor knowledge and usage of English grammar by secondary school students have manifested in the poor quality of essays produced and answers written for comprehension and summary in public examinations. This assertion lends credence to the WAEC Chief Examiners' Report (2013) when adducing reasons for students' poor performance in essay writing which provides avenue for English usage. The report states that:

Candidates recorded many-------- grammatical errors as this can cost them all the marks allowed for expression and mechanical accuracy. (pg.119).

The scenario painted in comprehension and summary is not in any way different as illustrated by the comments of WAEC Chief Examiner (2013) as follows:

A candidate cannot understand the content of a passage unless he understands the meaning of the word used. Many candidates failed to answer correctly ...... because they lack necessary grammatical tools to convey them. (pg. 123).

Efforts at scaling up the performance of students in aspects of English language that deal with grammar have led researchers to venture into the application of various strategies. Those studies, however, did not include the teaching of grammar which is the engine room of all expressive tasks. There is, therefore, the need to shift research focus to conscious teaching of the grammar of English language using grammar specific instructional strategies. Grammar teaching in the second- language classroom has constituted an important issue of debate in the last fifty years. The way grammar is -or has been-- considered has a direct and decisive influence on pedagogical grammars, learning processes and many other areas involved in second language teaching. Grammar, as a subsystem in a network of other linguistic sub-systems and sub-skills (Newby, 2003), has been attached different roles in the language classroom, reaching little consensus, not only about the particular items to be taught, but about when, or how, or even where to teach or learn.

A grammar-specific strategy canvassed by scholars is Explicit Grammar Instruction (EGI). According to Celce-Murcia and Larsen-Freeman (1999), Explicit Grammar Instruction is a conscious teaching of English grammar by connecting the 
ways people use the language (its function) with the structure (its form) they need to use in the communicative process. Scarcella (2003) emphasizes the importance of EGI by its ability to help learners develop the high level of communicative competence necessary for success in school and beyond.

Dutro and Moran (2003) averred that Explicit Grammar Instruction (EGI) offers the learners opportunities for meaningful practice and that it is only through meaningful practice that students will internalise the structures for fluency and automaticity. In the same vein, Teschner and Evans (2007) stressed the importance of providing English language learners with explicit instruction in the rules of grammar as they relate to syntax, voice, mood, tenses and other dimensions of the structure of the English language. They emphasized that conscious teaching of these items is essential for students to achieve a high level of language proficiency. Stathis and Gotsch (2008) identified two modes of Explicit Grammar Instruction as Direct Explicit Grammar Instruction (DEI) and Indirect Explicit Grammar Instruction (IEI).

Direct Explicit Grammar Instructional Strategy (DEI), according to Stathis and Gotsch (2008), is a teacher-directed instruction which involves a sequence of supports that are highly structured and practice-oriented. Explicit instruction involves modelling, observation, imitation or practice and corrective feedback during the course of instruction. Explicit instruction process moves systematically from extensive teacher input and little student responsibility and minimal teacher involvement at the conclusion of the learning cycle.

The effects of explicit instructional strategy on students' achievement in and attitude to learning have been revealed in a number of studies with varying levels of success. For example, Duke (2010) and Crown (2009) conducted separate studies to investigate the effects of explicit instructional strategy on comprehension and narrative writing respectively, and they reported that the strategy has a significant effect on students' achievement in these aspects of the English language. Komolafe (2010) examined the effects of explicit grammar and sentence combining instructional strategies on primary school pupils' achievement and attitude to essay writing and found that pupils exposed to composition instruction through these strategies performed better than those taught with the conventional lecture strategy. However, the gap identified in that study is that Komolafe used EGI as a single strategy without considering its two variants. The two modes of EGI documented in literature are Direct Explicit instructional strategy and Indirect Explicit instructional strategy on students' learning outcomes in English grammar (Stathis and Gotsch, 2008).

Larsen-Freeman (1999) argued that Grammar can be taught deductively through direct instruction. Deductive teaching refers to the form of explicit explanations of grammatical structures provided to learners orally or in writing (Ellis 
1997). It helps the teacher save time for the class. In this strategy, students are supplied with a rule (or perhaps, part of a rule) which they then apply, complete or amend in a task that requires to analyse data that illustrate its use (Ellis, 1997). For example, students may be given a rule about the simple past tense with a number of sentences and instructed to use the rule, to recognise which of the sentences are grammatical and which are ungrammatical. Learners are therefore quite dependent on the teacher's explanations or provision of grammar rules. It is this deductive teaching of grammar that Stathis and Gotsch (2008) referred to as direct explicit grammar instruction.

Deductive strategy, otherwise known as Direct Explicit Grammar Instruction Strategy, is a process in which learners are taught rules and given specific information about language. Then, they apply these rules when they use the language. Deductive instruction involves rule explanation by a teacher at the beginning of a lesson before students engage in language practice (Rabab'ah and AbuSeileek, 2007). Lin (2010:20) stated the characteristics of the deductive strategy as follows:

1. It is a rule- based teaching style that involves presentation or explanation before learners encounter how rules function in language.

2. It is one of the explicit teaching styles where students are exposed to the role of the language first raising their consciousness about the language they are learning.

3. When students' attention is drawn to grammatical forms in the input, the result is more efficient intake, showing that when grammar instruction and practice involve interpreting and attending to input, learners more successfully understand and produce the targeted grammatical structure over time than subjects not exposed to direct explicit grammar instruction.

Direct explicit grammar instruction encourages students to view grammar not just as isolated letters, words and phrases but also as a meaningful component of contextual language use (Paesani, 2005). Paesani contended that direct explicit grammar instruction draws students' attention to grammatical rules and forms which provide comprehensive and meaning bearing input.

Another mode of EGI is Indirect Explicit Instruction. Indirect explicit grammar instruction favours induction or learners' discovery of the grammatical rules through tasks and therefore does not involve giving grammatical explanations (Ellis, 2008). It implies a problem solving approach in which students are provided with data which illustrate the use of a specific grammatical structure which they analyse to arrive at some generalisation that accounts for irregularities in the data (Ellis, 1997). For example, students may be given a reading passage containing some illustrations of the use of the simple present and present continuous tenses and are required to "identify" the verbs in both tenses and then build a "rule" to explain their different functions. 
Briefly, from the given input and tasks, learners have to construct the grammar rules for themselves. This mode of Explicit Grammar instruction is used synonymously with Inductive teaching of grammar by Statchis and Gotsch (2008).

Indirect Explicit Grammar Instruction strategy involves limited teacher direction, with emphasis on students co-creating their learning with the teacher as a facilitator of their learning.The strategymay use social instructional approaches (learning with other students) or students working independently. It is often based on constructivist principles where students create meaning through active engagement and investigation. It promotes: (a) the student's point-of-view (b) teacher-student or student-student interaction (c) questioning to promote student's thought (d) nurturing of student reflection rather than emphasis on a single correct answer. It tends to use more inductive methods (leading students to discover concepts)

According to Harding \& Taylor (2005), the model involved in Indirect Explicit Grammar Instruction involves

i. Lead in (Explain what to do)

ii. Providing input(Sample structure) Consciousness -raising task (Sensitize learners to an underlying principle)

iii. Checking and Summarizing (Feedback) Practice (Independent practice)

Many studies have been carried out on Explicit Grammar instruction. For instance, Loyer (2010) conducted separate studies to investigate the effects of Explicit Instructional Strategy on grammar and narrative writing respectively and reported that the strategy had a significant effect on students' achievement in and attitude to these aspects of the English language without looking at the two modes of EGI which are of interest to this study, Fakeye's (1991) study on differential effect of deductive and inductive strategies on students achievement in written test of English grammar reported that inductive strategy was more facilitative of students' achievement in English grammar than deductive strategy. The gap in that study is that Fakeye examined the relative effectiveness of the two modes of EGI without considering how they would fare vis-à-vis the conventional lecture strategy.

Apartfrom teaching strategies, some other variables can interact with instruction to influence students' learning outcomes especially in English language classroom. One of such variables is class size. Performance of students in English language in general can be influenced by class size (Fabunmi, Brai-Abu \&Adeniji 2007; Adeyemi, 2008; Hartshorn, 2008 andAbioye, 2010). Asikhia (2010) observes that the problem of too large population of students in a classroom does not create a good condition for learning which can lead to poor academic performance of students. This view is shared by Aduwa-Ogiegbaen and Iyamu (2006) who also observe that 
most secondary schools are overcrowded and that teachers have little or no room to move around to give individual attention to students. Abioye (2010) is also of the opinion that when there are too many students in a class, effective learning will be hampered. This is because it may be very difficult, if not impossible, for a teacher in such a situation to meet the individual learning needs of the learners. Although the studies reviewed above show that the lower the class size or teacher-pupil ratio, the higher the students' achievement, Fabunmi, Brai-Abu and Adeniji (2007) believe that the relationship between class size and academic performance remains a major controversy and a subject of continuous research. This is particularly true when we consider the findings of Machado and Vera-Hernandez (2008) and Ibrahim (1992) who submit that class size seems to have little or no effect on teaching effectiveness and students' academic achievement. In the opinion of Machado and Vera-Hernandez (2008) class size could have positive or negative effects on students' academic achievement.

\section{Statement of the Problem}

The poor performance recorded by students in public examinations has been attributed to students' poor knowledge of the grammar of English which is reflected in the low quality of their oral and written communication. Most studies aimed at improving students' learning outcomes in oral and written communications such as activity, discussion and lecture methods were without conscious teaching of the rudiments of English grammar to help learners overcome their perceived weaknesses. Explicit Grammar Instructional (EGI) has, therefore, been canvassed. Studies have shown the effectiveness of EGI in improving students' learning outcomes in grammar without looking at the effects of its two modes on students' achievement in English Grammar and composition. Hence, this study would determine the effects of Direct and Indirect EGI on students' achievement in English grammar and composition in selected senior secondary schools in Ibadan Metropolis, Oyo State. The moderating effects of gender and class size would also be determined.

\section{Hypotheses}

The following null hypothesis was tested at 0.05 level of significance:

H0 $0_{1}$ : There is no significant main effect of treatment on students' achievement in English grammar.

\section{Signifiance of the Study}

The study revealed that Direct and Indirect Explicit grammar instructional strategies were effective in improving achievement in English Grammar. Findings from this study would also help teachers to make use of appropriate strategies in teaching English grammar through seminars, conferences and workshops to be organised by 
government and stakeholders. Finally, it would be useful to curriculum planners who are in constant search of appropriate teaching strategies for effective teaching/learning process in secondary schools.

\section{Methodology}

This study adopted the pretest- posttest, control group, quasi-experimental design using a $3 \times 2$ factorial matrix. Purposive sampling was used to select three local governments from Ibadan Metropolis. The three selected local governments were Ibadan North, North-East and North-West Local Governments. Purposive sampling was used to select three senior secondary schools from each local government making nine schools that were selected. An intact class of SS2 was selected from each school making a total of nine intact classes. The intact classes were randomly assigned to treatment groups such that three intact classes were in each of the three groups.

Six instruments constructed by the researcher were used in this study to collect data. They were English Grammar Achievement Test ( $r=0.87)$,Teachers' Instructional Guide on Direct Explicit Grammar Instructional Strategy, Teachers' Instructional Guide on Indirect Explicit Grammar Instructional Strategy Teachers Instructional Guide on Modified Conventional Strategy, Evaluation sheet for Assessing Teachers' Performance on the use of the Strategies $(=0.90)$.

Treatment lasted six weeks during which time students in the two experimental groups were exposed to English grammar instruction using direct and indirect explicit grammar instructional strategies respectively while the control group were taught English grammar using the conventional strategy. The English grammar concepts taught were Mood, Voice, Direct and Indirect speech, Question tags, Tenses and Sentence combining devices. The lesson steps of each strategy are stated below.

\section{Direct Explicit Grammar Instructional Strategy}

Step 1: Define/ Explain the Grammatical Concept

Step 2: State the rules guiding the use of the concept

Step 3: Generate sample sentences using the rules of guides.

Step 4: Students use teachers' model to generate their own sentences.

Step 5: Teacher provides correct feedback to students.

Step 6: Teacher recaps the rules to bring them into focus.

\section{Indirect Explicit Grammar instruction Strategy}

Step 1: Teacher announces the objectives of the lesson to the students.

Step 2: $\quad$ Teacher provides several sentences to exemplify the concept being taught 
Step 3: $\quad$ Through guiding questions, students are led to discover the underlying principles in the sample sentences given

Step 4: $\quad$ Students generate further sentences in accordance with the rules discovered.

Step 5: $\quad$ Teacher provides corrective feedback to students.

\section{Modified Conventional Strategy}

Step 1: $\quad$ Teacher defines the concept.

Step 2: $\quad$ She/he takes the students through the examples given in their reading text.

Step 3: $\quad$ She/ he sets them to do the exercises in their notebooks.

Step 4: $\quad$ Teacher goes round to mark their work.

Step 5: She/he does correction with them.

All the SSII students in experimental and control groups were exposed to pretest of English Grammar before treatment and posttests after treatment. Data collected were analyzed using descriptive statistics of frequency counts, mean and standard deviation. Also, inferential statistics of Analysis of Covariance (ANCOVA) was used to test all the hypotheses. In addition, estimated marginal means was computed to show differences in the mean scores of different groups. Scheffe post hoc test was used to determine the source of significant main effects among the groups. All hypotheses would be tested at 0.05 level of significance.

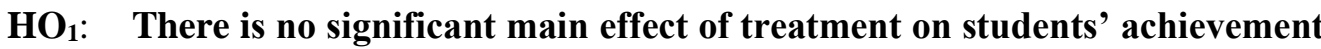 in English grammar}


Table 4.1: Summary of Analysis of Covariance on students 'achievement in English grammar

\begin{tabular}{|c|c|c|c|c|c|c|}
\hline Source & $\begin{array}{l}\text { Type III } \\
\text { Sum of Squares }\end{array}$ & DF & Mean Square & $\mathrm{F}$ & Sig. & $\begin{array}{l}\text { Partial Eta } \\
\text { Squared }\end{array}$ \\
\hline Corrected Model & 2029.308 & 18 & 112.739 & 3.453 & .000 & .185 \\
\hline Intercept & 6488.497 & 1 & 6488.497 & 198.715 & .000 & .421 \\
\hline PREGRAM & 77.481 & 1 & 77.481 & 7.373 & .125 & .009 \\
\hline \multicolumn{7}{|l|}{ Main Effect: } \\
\hline TRTGROUP & 258.147 & 2 & 129.074 & 7.373 & $000 *$ & .028 \\
\hline CLASS-SIZE & 131.984 & 2 & 65.992 & 2.021 & .134 & .015 \\
\hline \multicolumn{7}{|l|}{ 2-way Interactions: } \\
\hline TRTGROUP*CL & 6.900 & 2 & 26.748 & .106 & .900 & .051 \\
\hline & 256.223 & 4 & 3.450 & 1.962 & .101 & .028 \\
\hline Error & 8914.072 & 273 & 64.056 & & & \\
\hline Total & 156393.000 & 292 & 32.652 & & & \\
\hline Corrected Iotal & 10943.380 & 291 & & & & \\
\hline
\end{tabular}

*Significant at $\mathrm{P}<.05$

Table 1 shows that treatment had significant main effect on students 'achievement in English grammar $\left(\mathrm{F}_{(2,273)}=7.373 ; \mathrm{p}<0.05 ; \eta^{2}=0.028\right)$. Therefore, Ho $\mathrm{1a}_{\mathrm{a}}$ is rejected. Table 4.2 presents the magnitude of students 'achievement in English grammar across the groups.

Table 2: Estimated Marginal Means of students 'achievement in English grammar among the Treatment Groups

\begin{tabular}{|c|c|c|c|c|}
\hline \multirow[t]{2}{*}{ Treatment } & \multirow[t]{2}{*}{ Mean } & \multirow{2}{*}{$\begin{array}{l}\text { Std } \\
\text { Error }\end{array}$} & $\begin{array}{l}95 \% \\
\text { Interval }\end{array}$ & Confidence \\
\hline & & & $\begin{array}{l}\text { Lower } \\
\text { Bound }\end{array}$ & $\begin{array}{l}\text { Upper } \\
\text { Bound }\end{array}$ \\
\hline Direct Explicit & 21.95 & .222 & 21.39 & 22.37 \\
\hline Indirect Explicit & 21.88 & .213 & 21.36 & 22.55 \\
\hline Conventional & 15.57 & .235 & 13.09 & 19.05 \\
\hline
\end{tabular}


Table 4.2 reveals that students exposed to Direct Explicit Strategy had the highest achievement mean score (21.95), followed by those exposed to Indirect Explicit (21.88), followed by those exposed to Conventional strategy score (15.57). Table 4.3 presents Scheffe $^{\prime}$ post hoc analysis to reveal the source(s) of the significant effect.

Table 3: $\quad$ Scheffe' Post Hoc Analysis of students 'achievement in English grammar by Treatment Groups

\begin{tabular}{|l|l|l|l|l|}
\hline Treatment Groups & Mean & Direct Explici & Indirect Exp & Conventional \\
\hline Direct Explicit & 21.95 & & $*$ & $*$ \\
\hline Indirect Explicit & 21.88 & & & $*$ \\
\hline
\end{tabular}

Table 4.3 shows that students exposed to English Grammar Instruction through Direct Explicit Grammar Instruction had the highest posttest achievement scores $(\overline{\boldsymbol{x}}=21.95)$ followed by those exposed to indirect Explicit grammar instruction $(\overline{\boldsymbol{x}}=21.88)$ and control group $(\overline{\boldsymbol{x}}=15.57)$.

\section{Discussion of Findings}

\section{Main Effect of Treatment on Students' Achievement in English Grammar}

Treatment had significant main effect on students' achievement in English grammar. Those exposed to Direct Explicit Instructional Strategy had the highest posttest achievement mean score, followed by those exposed to Indirect Explicit Grammar instructional strategy and then by those exposed to conventional strategy. In Direct Explicit Grammar Instructional Strategy, students work in collaboration with their teacher to generate correct and acceptable sentences. The Indirect Explicit Strategy offers a classroom environment that encourages modelling, observation and corrective feedbacks during instruction. These allow students the opportunity to participate actively and relate directly with their classmates which leads to improved performance. Similarly, the high level of students' involvement in Indirect Explicit Instruction group encouraged interactions and active participation, through tasks, in classroom activities and this led to an improvement in students' achievement in English grammar. Rutherford, Sharwood and Smith (1988) have pointed to the fact that if students are made aware of the target language rules, their language acquisition will be facilitated. This finding also supports the submission of Rerrangya (2002), Thornbury (2005), Ellis (2008) and Amin (2009) that the teaching of grammar, using a wide range of models, had positive effects on improving secondary school students' writing. Further still, Amin (2009) conducted a research to determine the effectiveness of 
teaching grammar in context to reduce grammatical errors in students' writing. The result showed that students taught by teaching grammar in context make less grammatical errors in writing than those who are taught by teaching grammar through reading text. The result, however, disagrees with the findings of Olubodun (2014) that the strategy had no significant effect on continuing education students' achievement in English grammar.

Furthermore, Indirect Explicit Grammar Instructional Strategy was found to be more effective than the Modified Conventional strategy (control group), on students' achievement in English grammar. This result could be because the strategy is a learnercentred instructional strategy which provided learners with the opportunity to participate during the lesson. During treatment, the learners were fully involved. The high level of students' involvement enabled them to actively interact with the teacher which facilitates the learning process and provides corrective feedbacks. This affirms the findings of similar studies (Ellis, 2008; Hinkle, 2008) on the effectiveness of learner-centred instruction.

The Modified Conventional Strategy was the least effective on students' achievement on English grammar. This confirms the submissions of Ojedokun (2010) and Komolafe and Yara (2010) that the dependence on and/or the continued use of conventional instructional strategies cannot encourage learners to think critically and apply their knowledge in solving real-life problems.

\section{Conclusion}

The results of the study have shown that both Direct and Indirect Explicit Grammar Instructional Strategies are more facilitative in enhancing students' achievement in English Grammar than the modified conventional strategy. It could be concluded from this study that explicit teaching of English grammar is necessary for students to be grounded in the rudiments of English language.

\section{Recommendations}

Based on findings of this study, the following recommendations were made:

1 Direct and Indirect Explicit Strategies should be adopted as viable strategies for teaching and learning of rules and concepts in English grammar and English composition since they involve students' participation in their learning process.

2 Teachers of English language should be exposed to periodic in-service training programmes, seminars, workshops, and conferences for English language teachers to keep them abreast of innovative strategies such as Direct and Indirect Explicit Grammar Instructional Strategies 
3 The Nigeria Union of Teachers (NUT) and Nigeria English Studies Association (NESA) should organize regular conferences and seminar using Direct and Indirect Explicit Grammar Instructional Strategies for English language teachers.

\section{References}

Abioye, T. (2010). Managing language testing in Nigerian large classes: Process and prospects. Journal of English Language Teaching Vol. 3, 2: 82-87.

Adeyemi, T. O. (2008). The influence of class size on the quality of output in secondary schools in Ekiti State, Nigeria. American Eurasian Journal of Scientific Research 3, 1:7-14.

Aduwa-Ogiegbaen, S. E. \& Iyamu, E. O. (2006). Factors affecting the quality of English language teaching and learning in secondary schools in Nigeria. College student Journal.

Amin, C. (2009). Communication skills and mechanics of English. Enugu: John Jacobs classic publishers.

Asikhia, O. A. (2010). Students and teachers' perception of the causes of poor academic performance in Ogun state secondary schools: Implications for counselling and national development. European Journal of Social Sciences 13, 2: 229-242.

Celce-Murcia, M. (1991). Grammar pedagogy in second and foreign language teaching. TESOL Quarterly, 25, 459-480. Retrieved from http://www.hpu.edu/Libraries_HPU/Files/TESOL/TQD/VOL_25_3.pdf

Celce-Murcia, M. \& Larsen-Freeman (1999). Developing second language skills' theory and practice. 3rd edition San Diego-Harcourt Purace Jovanovich.

Crown, S. I. (2009).Using Explicit Instructional Strategies to Teach Narrative Writing. Teachers as learners: improving outcomes for Maori and Pasifika students through inquiry. Retrieved online from http://nzcurriculum.tki.org.nz/Inquiry on 17th December,2012.

Duke, N. K. (2001). Building Comprehension through explicit teaching of comprehension strategies. Presentation to the Second Annual MRA/CIERA Conference September 22, 2001. Michigan State University.

Dutro, S. \& Moran, C. (2003). Rethinking English language instruction: An architectural approach in English Learners: Reaching the Highest Level of English Literacy. Network, D.E.; International Reading Association. 
Ellis, R (2006). Current issues in the teaching of grammar: An SLA perspective. TESOL there is no significant main effect of students' 40/1: 83-107

Ellis, R (2008). Grammar in language teaching. In Hinkle, E. \& Fotos, S. (eds). New perspectives on grammar teaching in second language Classrooms. (pp. 1315) New York Rutledge.

Ellis, R. (1997). SLA Research and language teaching. Oxford: Oxford University Press.

Ellis, R. (2003). Task-based language learning and teaching. Oxford: Oxford University Press.

Evans, E. (2007). Analyzing the grammar of English $\left(3^{\text {rd }}\right.$ ed $)$. Washington, D.C.; Georgetown University Press.

Fabunmi, M.; Brai-Abu, P. \& Adeniji, I.A. (2007). Class factors as determinants of secondary school students' academic performance in Oyo state, Nigeria. Kamla-Raj Journal of Social Science 14, 3: 243-247.

Fakeye, D.O. (1991) Differential effect of deductive and inductive approaches on students' achievement in written Test in English grammar in two senior secondary schools in Ibadan M.Ed. Project, Department of Teacher Education University of Ibadan.

Federal Republic of Nigeria (2013). National policy on education. NERDC Press, Ikeja.

Fotos, S. (1994). Integrating grammar instruction and communicative language use through grammar consciousness-raising tasks. TESOL Quarterly 28 (2), 323351. Retrieved from http://www.jstor.org/stable/3587436.http://dx.doi.org/10.2307/3587436

Harding, K., \& Taylor, L. (2005.) International express. Oxford: Oxford University Press.

Hartshorn, J. (2008). The practice of English language teaching (4thed.). England: In Harmer, J. (2007). How to teach English. Oxford: Pearson Longman.

Hinkle, E. (2008). Teaching grammar in writing classes. In E. Hinkle, \& S. Fotos (Eds.). New perspectives on grammar teaching in second language classrooms (pp. 181-198). New York: Routledge. http://dx.doi.org/10.2307/3586980

Ibrahim, A.B. (1992). The A-level examination qualitative and qualitative data in the context of a performance monitoring system. PhD Thesis, University of Newcastle, U.K. 
Joint Admissions and Matriculation Board (2014). Brochure for the unified tertiary matriculation examination.

Komolafe, A. T. (2010). Effect of explicit and sentence combining strategies on primary school pupils' learning outcomes in English composition in Akinyele Local Government Oyo State. Unpublished Ph.D Thesis, Department of Teacher Education, University of Ibadan.

Komolafe, A. T. \& Yara, P.O. (2010). Sentence combining strategy and primary school pupils achievement in written English in Ibadan, Nigeria. European journal of scientific research 40(4) pp. 531-539.

Larsen-Freeman, D. (1999).Teaching language: from grammar to grammaring. Heinle: Newbury house.

Lindbland, M. (2010). Objectives for writing an essay. Database based on word net. demand media. West Coast.

Machado, M. P. \& Vera-Hernandez, M. (2008). Does class size affect the academic performance of first year college students? Retrieved March 30, 2011 from www.editorialexpress.com

Ojedokun R. I. (2010). Literature circle, semantic mapping and senior secondary school students' learning outcomes in summary writing in English language. Unpublished Ph.D Thesis, University of Ibadan.

Olubodun, O.A. (2014). Effects of three grammar units on academic achievement on extra mural students in English language examinations. A Ph.D seminar paper presented at the department of adult Education, University of Ibadan.

Paesani A. (2005). Focus on form instruction: Foundations, applications, and criticisms. The Reading Matrix 5 (1) 47-57.

Renandya, R. (2002). Grammar and the teaching of writing: limits and possibilities. Urbana. IL. National council of Teachers of English.

Rutherford, J., Sharword C. and Smith, C.B. (1988). Successful techniques in grammar instruction ERIC clearing house on reading and communication. Bloomington, IN, UXSA.

Rabab'ah, M. \& Abu Serleek J. (2007). Multimodal interacies: An introduction. In literacies, the arts and multimodalling. Virbana, IL: National council of Teachers of English.

Thornbury, S. (2005). Perspectives on second language acquisition (pp. 172-188). Lowe \& Brydone: Longman. 
West African Examinations Council (2009).WAEC chief examiners' report for the West African Senior School Certificate Examination (WASSCE).WAEC press.

West African Examinations Council (2011). WAEC chief examiners report for the West African Senior School Certificate Examination (WASSCE). WAEC Press.

West African Examination Council (2013).WAEC Chief Examiners' Report for the West African Senior School Certificate Examination (WASSCE).WAEC Press. 